\title{
Um olhar sobre as benzedeiras do município de Quirinópolis: entre a cultura, a religião e a medicina popular
}

\author{
Gilson Xavier de Azevedo* \\ Carolina Teles Lemos**
}

\section{Resumo}

O objetivo desta pesquisa é o de situar a figura das benzedeiras a partir de três contextos a saber: a cultura, a religião e a medicina populares. O presente estudo se justifica a partir das muitas benzedeiras encontradas no município de Quirinópolis, 23 ao todo, sudoeste do Estado de Goiás entre os anos de 2013 e 2016. O problema central é verificar como se dão as condições de permanência dessas mulheres como uma espécie de artefato social em tempos de secularização. Trabalha-se como hipótese o fato de que as práticas de benzeção são uma forma de racionalização simbólica do mundo e de esperançamento, o que justifica sua procura. A metodologia empregada na pesquisa é a de um estudo exploratório de caráter bibliográfico com pesquisa de campo, utilizando como instrumento de pesquisa um questionário fechado aplicado a dez mulheres. Realizou-se a análise qualitativa dos dados por meio dos conceitos de 'popular' e 'oficial' em relação aos três contextos acima indicados. Aponta-se, por resultado, a constatação de que as condições de permanência das práticas de benzeção tendem a durar por muito tempo ainda ou talvez enquanto a humanidade perdurar.

Palavras-chave: Religião; Cultura; Medicina; Popular; Benzedeiras.

\section{A Look at the Beers of the City of Quirinópolis: Between Culture, Religion and Popular Medicine}

\section{Abstract}

The aim of this research is to locate the figure of the blessing from three contexts namely: popular culture, religion and medicine. The present study is justified from the many benzedeiras found in the municipality of Quirinópolis,

* Doutor em Ciências da Religião pela PUC-GO (2014-2017- BOLSISTA FAPEG) (gilson. azevedo@ueg.br).

** Doutora em Ciências Sociais e da Religião pela Universidade Metodista de São Paulo (1998) (cetelemos@uol.com.br). 
23 in all, southwest of the state of goiás between 2013 and 2016. The central problem is to verify how the conditions of residence of these women as a species occur. of social artifact in times of secularization. It is hypothesized that blessing practices are a form of symbolic rationalization of the world and of hope, which justifies their search. The methodology used in the research is an exploratory study of bibliographic character with field research, using as a research instrument a closed questionnaire applied to ten women. Qualitative data analysis was performed through the concepts of 'popular' and 'official' in relation to the three contexts indicated above. As a result, it is pointed out that the conditions of permanence of blessing practices tend to last a long time or perhaps as long as humanity endures.

Key-words: Religion; Culture; Medicine; Popular; Benzedeiras.

\section{Una mirada a las cervezas de la ciudad de Quirinópolis: entre cultura, religión y medicina popular}

\section{Resumen}

El objetivo de esta investigación es localizar la figura de la bendición desde tres contextos, a saber: cultura popular, religión y medicina. El presente estudio se justifica por las muchas benzedeiras encontradas en el municipio de Quirinópolis, 23 en total, al suroeste del estado de goiás entre 2013 y 2016. El problema central es verificar cómo se producen las condiciones de permanencia de estas mujeres como especie. de artefactos sociales en tiempos de secularización. Se presume que las prácticas de bendición son una forma de racionalización simbólica del mundo y de la esperanza, lo que justifica su búsqueda. La metodología utilizada en la investigación es un estudio exploratorio de carácter bibliográfico con investigación de campo, utilizando como instrumento de investigación un cuestionario cerrado aplicado a diez mujeres. El análisis de datos cualitativos se realizó a través de los conceptos de 'popular' y 'oficial' en relación con los tres contextos indicados anteriormente. Como resultado, se señala que las condiciones de permanencia de las prácticas de bendición tienden a durar mucho tiempo o quien sabe mientras la humanidad perdure.

Palabras clave: Religión; Cultura; Medicina; Popular; Benzedeiras.

\section{Introdução}

O ser humano desenvolveu ao longo de sua história, diversos mecanismos para interpretar e inserir-se no mundo. A religião é apenas um desses mecanismos. Dentre os muitos agentes religiosos que atuam nesse contexto, as benzedeiras ganham destaque. De acordo com Maciel e Guarim Neto (2006), a presença das benzedeiras no Brasil, data do século XVII. 
Inseridas em seu meio social, na maioria dos casos periférico ou campesino, essas mulheres, por meio do conhecimento que desenvolveram de plantas e técnicas de cura, davam resposta e esperança de cura aos que não tinham nem acesso à medicina oficial, nem aos medicamentos psicotrópicos comercializados. Se a medicina não chegava aos muitos recantos do país, a cultura erudita e a religião oficial também não se fizeram presentes, de modo que a benzedeira reuniu em si esses três arquétipos: cultural, religioso e médico.

A fundamentação da pesquisa situou-se nos clássicos da sociologia, como um referencial que possibilitasse o enquadramento proximal do tema 'benzedeiras', de maneira a lançar um olhar que, de início, fosse quase que puramente sociológico sobre o referido tema, em especial, no tocante ao processo de racionalização do ocidente e, portanto, das práticas que tencionou-se analisar.

Para tanto, debruçou-se sobre os textos de Max Weber (1991; 1982), dadas as suas pesquisas sobre o processo de racionalização, além de sua investigação, no campo religioso, sobre as figuras do sacerdote, do profeta e do mago, de modo que se entendeu que esse teórico poderia servir de referencial de análise sobre a prática das benzedeiras, sem muito risco de distanciar o resultado da essência do autor nesta interpretação.

Depois, na interpretação de Pierre Bourdieu (2007), pôde-se compor certo aprofundamento sobre a linha da sociologia compreensiva, ao considerar-se, em especial nesse autor, a questão do processo histórico de desenvolvimento socioprodutivo do Ocidente ora descrito por Weber, e assim, propor uma releitura da figura dos agentes especializados de cura e entender melhor a atuação das benzedeiras em seu cotidiano de orações, poções e curas.

Vislumbrar as benzedeiras dentro do escopo da Ciência da Religião é entender que a religião e as ciências sociais constituem campos abertos e vastos de atuação de agentes especializados e não especializados dos mais variados segmentos, sejam eles oficiais ou não. As benzedeiras estão igualmente inseridas em um contexto em que o sistema de crenças que elas alimentam ou que se retroalimenta na relação com elas, permite ao cientista da religião investigar ambos os campos de forma rigorosa, pelos já mencionados vieses da cultura, religião e medicina.

A agente da benzeção ou benzedeira está inserida ainda em um contexto que expressa a construção de um imaginário e, com esse, de um conjunto de representações variadas no campo da cura. A grande 
questão que parece surgir é: e se as benzedeiras não tivessem existido, o que fariam as pessoas que precisassem de uma cura ou um emprasto ${ }^{\prime}$ ? Nessa proposição, as benzedeiras parecem ter passado a existir justamente quando o conjunto de representações de cultura-religião-saúde emergiu sem a presença institucionalizada de entidades e, sobremaneira, do Estado como antecedentes históricos claros de tal constituição.

Ainda considerando o surgimento das benzedeiras enquanto algo necessário e enviesado na tessitura dos processos históricos da formação societária, como cientista da religião, debruço-me, no decorrer desta pesquisa, para considerar a participação histórico-social das benzedeiras, enquanto sujeitos e agentes, por meio de três vertentes que me pareceram claras, a saber.

$\mathrm{Na}$ vertente cultural, nas linhas cultura, cultura formal e cultura popular, entender as práticas das benzedeiras é entender os processos culturais, nos quais estão inseridas. Na vertente religiosa, nos segmentos religião, religião oficial, religiosidade popular, catolicismo, buscar entender como as religiões, e mais especificamente a religiosidade popular, interferem em processos de salvação pessoal, é também lançar luz ao problema das práticas das benzedeiras. Em terceiro, na vertente medicinal, buscar compreender as representações de saúde-doença-cura, nas linhas medicina formal, medicina alternativa que os indivíduos constroem nas situações diversas que vivenciam, e, ao mesmo tempo, clarificar os processos socioculturais pelo viés da religiosidade.

No primeiro caso, busca-se entender os elementos culturais no entorno das benzedeiras e essas como artefato sociocultural; no segundo, os aspectos religiosos da prática de benzeção, e, por último, a relação entre benzeção e medicina popular, de modo que ambas as localizações se dimensionam como lócus ou babitus (BOURDIEU, 1990, p. 158) de observação das benzedeiras no contexto social hodierno, do qual participam em sua totalidade, sendo que na estrutura saúde, inter-relacionam-se à cultura e à religião.

Mesmo sendo buscada por classes mais abastadas, tais como artistas, médicos e até religiosos, a figura da benzedeira é atualmente a expressão quase plena da cultura popular ou não formal, da tradição, da força natural, selvagem, divina, eterna, imutável e que não mostra prescindir de riqueza e bens para existir. É nesse contexto que elas estão com seus chás, ramos, rezas, conselhos, garrafadas, terços e salve-rainhas.

Palavra utilizada pelas benzedeiras e as pessoas que as procuram, para designar emplastro. 
Um olhar sobre as benzedeiras do município de Quirinópolis: 119 entre a cultura, a religião e a medicina popular

Com a ideia de que 'filho de pobre sara torto', muitos cidadãos têm, por vezes, apenas as palavras de conforto e a mão das benzedeiras para intervir em situações de doenças que acometem crianças, adultos, idosos, ricos e pobres. Não sendo oficial, a medicina popular recolhe da tradição oral o uso de orações e plantas para curar o que é passível de cura através de tais meios. É na medicina formal e em sua ausência nas periferias que emerge a prática da cura pelo benzimento, chá, garrafada, ervas e sinais.

Desse modo, o presente artigo expõe os resultados de pesquisa doutoral, situando o município onde se deu o estudo, os sujeitos da pesquisa, a metodologia adotada e os resultados da mesma.

\section{Caracterização do município de Quirinópolis, Goiás}

Segundo Urzedo (2014), o município de Quirinópolis, fundado em 31 de dezembro de 1943, está situado na microrregião sudoeste do Estado de Goiás, na Região Centro-Oeste do país, localiza-se ao sudoeste de Goiânia, capital do Estado, a cerca de $285 \mathrm{~km}$ de distância. Sua população estimada pelo IBGE em 2019 é de 50.065 mil habitantes. Ocupa uma área de 3.780 $\mathrm{km}^{2}$, sendo que sua área territorial representa $1.1115 \%$ da área do Estado, $0.2362 \%$ da área da Região Centro-Oeste e $0.0445 \%$ da área do Brasil. Do total de sua área, $7,8955 \mathrm{~km}^{2}$ estão em perímetro urbano, sendo que $84,42 \%$ de sua população vive em área urbana, e $15,58 \%$ vive na zona rural. O município de Quirinópolis está situado na Mesorregião do Sul Goiano a uma latitude $18^{\circ} 26^{\prime} 54^{\prime}$ S', longitude $50^{\circ} 27^{\prime} 06^{\prime} \mathrm{W}$ e a uma altitude média de 541 metros de altitude.

A economia do município de Quirinópolis foi sempre predominantemente agrícola. Até 1970, a população rural era superior à urbana. Muito distante da Capital, Goiânia, na época o acesso era pouco devido às estradas ruins, mesmo para a cidade desenvolvida mais próxima que é Rio Verde. Por esse motivo, os moradores adotavam práticas populares de saúde e religião, dado que mesmo sendo uma cidade que tem como origem a Freguesia de Nossa Senhora da Abadia, apenas nos anos 70 é que a paróquia como o mesmo nome foi erigida (CÂNDIDO, 2010).

Para Maciel e Guarim Neto (2006, p. 7), na ocupação de tais regiões, "pessoas inter-relacionam-se e os saberes são experimentados e revelados através de um conhecimento que tradicionalmente consolidou-se e permeia o cotidiano dessas pessoas", onde o pano de fundo são as plantas, os cantos, as rezas, as curas, os chás, as benzições e o alento de cura, "pois nesse 
locus de vivências e experiências, o 'saber-fazer' é importante para a própria continuidade da vida social, cultural e econômica e também imprescindível para a manutenção de práticas de cura, gradativamente reduzidas pela expansão das áreas urbanas, que buscam copiar o que acontece nos grandes centros urbanos" (MACIEL; GUARIM NETO, 2006, p. 7).

Assim como outras regiões do município e do Estado, Quirinópolis foi o local perfeito para o surgimento da figura das benzedeiras, e ainda o é, dado que esse arquétipo social não fora extinto.

\section{Caracterização dos sujeitos de pesquisa}

As entrevistadas têm média etária de 64 anos, a maioria é casada, sendo uma amigada (amasiada) e uma solteira. A maioria cursou o $4^{\circ}$ ano e tem em média 4 filhos. Todas têm casa própria. Realizei as entrevistas em suas casas, à exceção de duas que entrevistei em seus locais de trabalho.

Em relação ao local de nascimento, apenas três declararam ter nascido em Quirinópolis, outras três em outras cidades de Goiás, três em Minas Gerais e uma no Estado de São Paulo.

Em média, residem em Quirinópolis há 35 anos. Sobre seu bairro, estão localizadas mais em regiões periféricas da cidade, à exceção de três delas. Todas disseram ter boa ou ótima relação com sua comunidade.

A primeira entrevista aconteceu em 06 de julho de 2014 com a benzedeira Dna. Dalila², nascida em Guarapuava interior de São Paulo, 67 anos, casada. Ela firma que sua casa é própria e que mora em Quirinópolis há 27 anos, no bairro Jardim Bom Pastor e considera que possui boa relação com a comunidade. Tem o $4^{\circ}$ ano primário em seus estudos e teve cinco filhos.

A segunda entrevista foi feita no dia 22 de julho de $2014 \mathrm{com}$ a Dna. Valdivina, nascida em Itumbiara interior de Goiás, 83 anos, casada. Também afirma que a casa em que mora é própria, no centro da cidade, em Quirinópolis, lugar que habita há 63 anos e considera que possui boa relação com a comunidade. Tem o $4^{\circ}$ ano primário de estudos e teve oito filhos.

A terceira entrevista se deu no dia 02 de setembro de 2014, com Dna. Adelícia, nascida em Santa Helena, interior de Goiás, 63 anos, que se diz amigada (amasiada) há 40 anos, como diz ela: "amigado com fé, casado é". Afirma que sua casa é própria, originária de apoio recebido da prefeitura local. Diz morar em Quirinópolis há 35 anos, no bairro Tonico Bento, e considera

2 Os nomes das entrevistadas aqui apresentadas são fictícios, visando resguardar a privacidade e o anonimato das mesmas. 
Um olhar sobre as benzedeiras do município de Quirinópolis: 121 entre a cultura, a religião e a medicina popular

que possui boa relação com a comunidade. Nunca estudou. Tem apenas um filho. Veste roupas simples e tem hábitos simples também.

A quarta entrevista feita no dia 11 de setembro de 2014 com Dna. Sebastiana, nascida em Quirinópolis na Fazenda Paredão, tem 74 anos, casada há 55 anos. Ela afirmou que sua casa é própria e que mora em Quirinópolis há cinco anos, no bairro São Francisco, desde que veio da fazenda onde residiu por muitos anos, e considera que possui uma pequena relação com a comunidade. Estudou somente o $1^{\circ}$ ano e teve quatro filhos. Dna. Sebastiana aprendeu a benzer com a mãe e a avó, já tardiamente, aos vinte anos. Reconhece que em sua época de moça nova, era importante uma jovem saber o ofício da benzeção, justamente para que isso indicasse que essa tinha vocação para ser mãe, sendo ainda uma forma de integração social. Seu marido deu testemunho de ter recorrido às orações dela muitas vezes, não só para si, mas para animais de sua propriedade rural também.

A quinta entrevista que realizei no dia 13 de setembro de 2014 com Dna. Marly, nascida em Quirinópolis, 47 anos, solteira. Sua casa é própria. Afirma morar em Quirinópolis há 14 anos, desde que retornou para cá, atualmente no bairro Alexandrina, e considera que possui ótima relação com a comunidade. Estudou até o $3^{\circ}$ ano, e teve um filho. Dna. Marly foi a benzedeira mais performática (termo extremamente denso de significados) das entrevistadas, no sentido de que possui diversos elementos místico/carismáticos em sua prática. Toda a chegada da sua casa, que é um grande quintal, está repleta de elementos sobre a benzeção. Na porta da casa tem uma placa indicando os dias em que benze (somente às quintas). São cinco bancos de madeira sob frondosa mangueira, onde atende seus vários reclamantes toda semana.

A sexta entrevista, no dia 14 de setembro de 2014 com Dna. Marieta, mãe de Dna. Marly, de quem se fez o relato anteriormente, nascida em Pirajuba, interior de Minas Gerais, 73 anos, casada. Sua casa é própria, mora em Quirinópolis há 54 anos, no bairro Municipal e considera que possui boa relação com a comunidade. Estudou até o $4^{\circ}$ ano e teve sete filhos. Dna. Marieta foi quem ensinou Dna. Marly a fazer as orações, muito embora eu deva fazer uma distinção entre o estilo de benzeção de ambas, dado que Marly hoje trabalha com oração espontânea e com o que vem aos seus sentidos no momento da oração, é intuitiva; e Dna. Marieta sabe as muitas orações, e as utiliza de cor.

A sétima entrevista se deu com Dna. Algeníria, no dia 16 de setembro de 2014. Dna. Algeníria nasceu na Fazenda Corredeira, no município 
de Quirinópolis, tem 61 anos, e é casada. Sua casa é própria, mora em Quirinópolis há 29 anos, desde que deixou a fazenda e passou a residir na cidade, estabeleceu residência no bairro Municipal, e considera que possui uma relação um pouco discreta com a comunidade. Estudou apenas o $1^{\circ}$ ano e teve dois filhos.

Neta de escravos, a oitava entrevistada desta pesquisa no dia 16 de setembro de 2014, foi Dna. Maria, que é cozinheira nas dependências do CMEI Nossa Sra. da Abadia. A entrevistada nasceu em Santa Vitória, Minas Gerais, tem 56 anos, e é casada. Sua casa é própria, mora em Quirinópolis há 9 anos, e desde que para cá veio, reside no bairro Alphaville; considera que possui uma relação discreta com sua comunidade, dado que trabalha o dia todo, de modo que sua prática de benzeção é aleatória, mas que ela afirma tê-la herdado da mãe e ocorre geralmente na creche onde é merendeira. Declara ter estudado até o $2^{\circ}$ ano e teve cinco filhos.

A nona entrevista, foi feita com Dna. Cleuza, também nas dependências da Creche Nossa Sra. da Abadia, na tarde no dia 16 de setembro de 2014. Nascida em Quirinópolis, Goiás, tem 54 anos, e é casada. Sua casa é própria, mora em Quirinópolis há 22 anos, no bairro Pedro Cardoso, desde que aqui reside, e considera que possui uma relação boa com sua comunidade. Realiza a benzeção de forma também aleatória e na creche onde é auxiliar de sala. Estudou até o $4^{\circ}$ ano e teve dois filhos. Dna. Cleuza atua há muitos anos como educadora e não se considera uma benzedeira na totalidade do termo, mas declara que, ao longo da vida, foi aprendendo e utilizando algumas orações em momentos em que essas eram necessárias e percebeu que 'foi dando certo’. Acredita que sua missão é alegrar as colegas do CMEI.

A última entrevista realizada, quando se visitou Dna. Joana D Arc dos Reis Munis, foi no dia 07 de outubro de 2014. Mulher que se considera simples, mas controlada financeiramente, conforme ela mesma me disse e constatei na visita a sua casa. Dna. Joana D’Arc nasceu em Veríssimo, Minas Gerais, tem 59 anos, e é casada. Afirma que sua casa é própria e que mora em Quirinópolis há 41 anos, no bairro Capelinha, desde que para cá veio; considera que possui boa relação com a comunidade. Diz que estudou até o $4^{\circ}$ Ano primário e teve duas filhas. Conheci Dna. Joana no CMEI onde meus dois filhos receberam os cuidados pedagógicos. Ela foi a primeira benzedeira com quem meu filho esteve para receber oração. Nesse campo, ela se mostra bastante propositiva e forte na oração, no sentido de acreditar piamente naquilo que reza. Não foi observado em sua casa a presença de 
santos ou elementos religiosos, nem mesmo em sua vestimenta, tais como correntes ou terços.

A condição de permanência social das benzedeiras, aqui entendida como cultura residual a que se refere esta pesquisa, passa pelo viés econômico, vertente esta que se mostra importante na transversalidade das estruturas que ora se analisa.

A respeito da condição econômica das benzedeiras ora entrevistadas, foram propostas quatro perguntas, e todas as benzedeiras entrevistadas declararam possuir residência fixa; apenas três têm função de trabalho fora de casa, embora se deva aqui ressaltar que apenas duas das dez benzedeiras entrevistadas denotaram viver exclusiva e cotidianamente para sua prática, dado que as demais são aposentadas ou pensionistas e não têm a prática da benzeção como rotina nem cotidiana, nem de subsistência.

Sete delas somente são donas de casa além de serem benzedeiras. Nenhuma das benzedeiras declarou cobrar pela benzeção, entretanto três disseram receber presentes com certa frequência em retribuição à sua prática, das quais duas disseram que já receberam presentes, inclusive de grande valor. $O$ fato de receberem algo em troca de sua prática não representa também que sejam mulheres abastadas de presentes e retribuições financeiras, ao contrário, são simples e demonstram simplicidade em sua fala, movimentos, vestimentas, olhar e trato, casa, móveis.

\section{Métodos e técnicas aplicadas à pesquisa}

Constrói-se como escopo, verificar qual o lugar em que estão situadas as práticas que compreendem ações, orações, chás e elementos religiosos daquelas que aqui chamou-se de 'as benzedeiras'. As práticas que permeiam o cotidiano dessas mulheres, as quais decidiu-se pesquisar e acompanhar mais de perto, estão arraigadas à tessitura da cultura, da medicina e do catolicismo populares, de modo que, dessa grande estrutura que é a cultura oficial, emerge a cultura popular; e de ambas, emergem, historicamente, a religião e as diversas manifestações religiosas, incluindo aqui a religiosidade popular e, dessa, vão decorrer tanto o catolicismo quanto a medicina popular.

Como o estudo empírico (entrevista), que foi proposto, está situado em um contexto citadino e interiorano, entendo que os elementos culturalidade, regionalidade e saúde vão incorrer em alguns momentos desta discussão. Tenho ainda por certo que o panorama religioso da região Centro-Oeste, e da cidade de Quirinópolis, onde o estudo de campo se deu, é tão denso de significados 
quanto em qualquer outra região do país, quiçá do mundo. De mesmo modo, as formas de compreensão desse enorme conjunto de fenômenos que permeiam as práticas religiosas das benzedeiras, e porque não dizer populares de modo geral, exigem, primeiramente, um olhar bibliográfico acurado.

Após o projeto de pesquisa, referente ao estudo que aqui se delineou, ter passado pelo Comitê de ética da PUC-GO e ter sido aprovado sob o número: CAAE: 28771614.3.0000.0037, sem necessidade de apreciação no CONEP (Conselho Nacional de Saúde - Ministério da Saúde), iniciou-se as entrevistas.

Dentro do exposto, na trajetória de estudos sobre religião de um dos autores deste artigo, o tema 'as benzedeiras' não foi abordado nenhuma vez na forma de leitura ou pesquisa, de modo que, no ano de 2011, o filho de um dos autores, com um ano de vida à época, foi acometido de algumas doenças relacionadas à falha do sistema imunológico, em decorrência do período de adaptação no CMEI, ora escolhido pelos pais para sua Educação Infantil. Depois de passarmos por vários médicos da cidade, foi-nos sugerido procurar uma benzedeira para que pudéssemos submetê-lo a alguns rituais de benzeção, de modo a buscar a 'cura definitiva' para o problema desconhecido por nós e, aparentemente, pelos médicos que procuramos.

Nesse sentido, fizemos a visita à benzedeira indicada pela educadora da criança na época, e tal benzedeira 'diagnosticou-o' do que chamou de “mal de simioto". Marcamos o 'tratamento' que durou cinco semanas. Depois desse, a benzedeira nos mostrou um caderno indicando gente 'importante' da cidade, na visão dela, que havia passado pelo mesmo tratamento, inclusive filhos de médicos. Doença ou não, tratamento ou não, após uma visita a um pediatra de Goiânia e alguns remédios de imunização, meu filho adaptou-se prontamente ao CMEI, onde foi cuidado até 2015, quando ingressou no Ensino Fundamental em uma escola da rede municipal.

De nossas observações durante e após o referido 'tratamento' citado anteriormente, notamos que, em Quirinópolis, cidade natal de um dos autores deste artigo, a figura das benzedeiras era recorrente, e fazem uso de sua prática, diversos seguimentos sociais e religiosos. Depois, passamos

\footnotetext{
Mal de simioto (de simio $=$ macaco) é o nome popular, em algumas regiões do Brasil (MT, MS, GO) da desnutrição causada em crianças pequenas por alergia ao leite de vaca ou à incapacidade de digerir o mesmo. A doença aparece normalmente quando o aleitamento materno é substituído por leite de vaca em pó. Muitas vezes o intestino de um bebê não produz as enzimas necessárias para digerir a lactose de origem animal. Normalmente desaparece com a volta ao aleitamento materno ou por ama-de-leite ou substituição por outro tipo de alimento a critério médico.
} 
Um olhar sobre as benzedeiras do município de Quirinópolis: 125 entre a cultura, a religião e a medicina popular

a observar que as mesmas pessoas que as procuravam, utilizavam-se dos préstimos de suas religiões de origem e dos serviços de saúde pública/ privada, concomitantemente, de modo que isso me fez refletir sobre qual seria a inserção dessas mulheres nesta sociedade em específico, mas também dentro do universo da literatura na área de ciências da religião.

Passou-se a investigar e observar mais de perto o fenômeno da presença social das benzedeiras e de suas práticas de benzeção, ainda durante o meu mestrado. Notamos, nas primeiras pesquisas, sustentado pelas leituras de Max Weber (1991), que tanto as chamadas religiões oficiais quanto as formas religiosas populares, como no caso das benzedeiras, perduraram no decorrer dos séculos, sofrendo, claro, algumas variações não tão substanciais. Notamos, ainda, que tal viés weberiano nos levaria a um entendimento do tema que, necessariamente, passaria pelo enquadramento sociológico, já mencionado, por meio do qual, busca-se a interpretação do sentido da ação social, no caso, das práticas cotidianas das benzedeiras, sintetizadas no método de interpretação, no qual estão unidas à compreensão e à explicação de tais práticas enquanto fenômenos sociais.

Para desenvolver tal pesquisa, debruçamo-nos sobre livros, artigos e autores que pudessem nos auxiliar a entender mais de perto esse fenômeno antes de nos aventurar na pesquisa de campo. Mesmo estando o projeto aprovado pelo Comitê de Ética da Pontifícia Universidade Católica de Goiás e as entrevistas autorizadas por meio de assinatura do Termo de Consentimento Livre e Esclarecido - TCLE, optamos por produzir denso e rigoroso material teórico interpretativo que me desse suporte nas entrevistas de campo, fazendo então, sucessivas comunicações em eventos para observar as contribuições que, porventura, surgissem nas discussões e debates.

Deste modo, situa-se esta investigação como parte de puma pesquisa científica de composição de tese de doutoramento em Ciências das Religiões. Seu enquadramento se dá como uma pesquisa empírico-exploratória, de caráter interpretativo e revisional bibliográfico, com pesquisa de campo. Considerou-se o viés da sociologia (WEBER, 1999, 1982; BOURDIEU, 1989, 1990, 1991, 1996, 2004) e da compreensão dos conceitos de cultura e cultura religiosa de análise qualitativa das informações bibliográficas coletadas e dos dados de campo referentes ao caso das benzedeiras e sua permanência no contexto atual, ora mencionado, tendo por tese o trânsito de tais práticas pelo viés da cultura oficial e popular e, em seguida, pela religião/religiosidade/ catolicismo e medicina popular. 
As entrevistas de campo aconteceram por meio da aplicação de questionário fechado, contendo 58 questões, submetido a 10 benzedeiras, sendo que 23 foram mapeadas, dessas, uma recusou-se a ser entrevistada, e as demais não participaram da entrevista por habitarem na zona rural. As entrevistas ocorreram de forma individual nos locais de moradia das benzedeiras ou em seu local de trabalho. As entrevistadas tiveram liberdade para responder às questões do formulário oralmente e acrescentar informações que julgassem importantes. Foram efetuadas caminhadas pelos quintais, hortas, jardins e roças das informantes, que apontavam plantas e indicavam o nome vulgar da espécie, as formas de uso e outras informações, além da indicação de uma oração que fosse a mais utilizada por cada uma.

Todas as entrevistas foram filmadas com câmera própria, além de terse feito anotações durante o transcurso dessas, sendo acordado que apenas o entrevistador teria acesso aos vídeos e que em nenhum momento eles seriam cedidos a outrem, e que as imagens de cada uma das entrevistadas poderiam ser divulgadas por meio de fotos. A pesquisa de campo iniciou-se em julho de 2014 e pôde ser finalizada em outubro de 2015. As benzedeiras foram indicadas por familiares, amigos, conhecidos e reclamantes ou pelas pessoas que as procuram, pedindo a reza/benzeção. Os nomes das benzedeiras aqui apresentados são fictícios, para resguardar o anonimato e a privacidade das mesmas.

\section{Resultados e discussão}

A teoria econômica de Weber (1991, p. 279-320; 1982) considera que a sociedade, na qual ele estava inserido, era resultante de um conjunto histórico de fatores econômicos, sociais, políticos e culturais. Ao analisar esse conjunto, Weber $(1991 ; 1982)$ procurou identificar o processo de racionalização do ocidente. Há de se ressaltar que mesmo desencantada, uma sociedade racionalizada recorre a mitos e crenças variados na busca de soluções para problemas do cotidiano (WEBER, 1991, p. 279-282). Seria como recobrar o adágio inscrito no Oráculo de Delfos, no qual se lê: "Invocado ou não, o deus está presente". Por sua vez, uma sociedade racionalizada para Weber (1982, p. 165), seria uma sociedade em que o comportamento humano se instrumentaliza. Para Willame (2012) a demonstração que Weber faz dos diferentes tipos de racionalidade e da contribuição dessas, no tocante à religião, é fator determinante para o desenvolvimento do capitalismo. 
Um olhar sobre as benzedeiras do município de Quirinópolis: 127 entre a cultura, a religião e a medicina popular

Em Economia e Sociedade I, Weber (1991, p. 279-281) afirma que a prática religiosa seria a responsável pela conquista da felicidade e em sua decorrência, de uma vida longa para quem faz orações (benze) e para quem as recebe (é benzido).

Willame (2012) entende que há uma recusa em Weber de associar o religioso ao irracional, mas, ao contrário, ele entende que foi justamente a ação religiosa, em suas formas de dominação, que exerceu forte influência sobre a construção do processo de racionalização, dado o vínculo social que a religião gera e sua forma de dominação.

Weber (1991, p. 322), após apresentar os principais agentes do campo religioso, como sacerdote, o profeta e o mago, ainda acrescenta à sua tipologia social a figura do místico, um tipo caracterizado por uma experiência pessoal imediata e distante das formas objetivas e formais de crença, o que se aproxima da perspectiva do depoimento a seguir: "Eu sinto uma força muito grande lá em casa, acho que lá é lugar santo sim, porque todo dia eu rezo lá né, peço proteção, peço os guia pra ficar lá, me ajudar. Já rezei mais, morava na roça, quando meus filho era pequeno tinha medo de acontecê algo com eles, então eu rezava muito, mas benzê mesmo foi depois de adurta" (ENTREVISTA COM DNA. MARIA, 16/09/2014).

O depoimento de Dna. Maria aproxima-se da experiência pessoal descrita por Weber (1991, p. 323) e que necessariamente se distancia de práticas institucionalizadas; ao contrário, são cotidianas, populares e de livre acesso. Conforme se apontou no depoimento e na teoria weberiana.

Nessa perspectiva, entende-se que a benzedeira age isoladamente, inclusive da Igreja Católica, nunca ou dificilmente em conjunto ou congregação, o que lhe garante certa autonomia ritual e religiosa em termos gerais. Talvez aqui se encontre um dos motivos de as benzedeiras terem se consubstanciado ao processo histórico, pois não cobram por seus serviços; foi o que se percebeu, indutivamente, nas falas das entrevistadas que consultei, bem como na literatura pesquisada; depois, atendem em geral em casa; recebem doações, agradecimentos que lhes garantem boa subsistência, e, em geral, têm família, elementos agregadores à sua prática e economia, que dispensam maiores exigências burocráticas.

Na mesma direção de Weber, Pierre Bourdieu (2007), francês de origem campesina e filósofo de formação, propôs uma análise sociológica do sistema religioso da teoria religiosa weberiana que parte do sentido da ação e não da revelação, ou seja, dos aspectos religiosos daquela. Segundo Bartz 
(2007, p. 33): “ao apresentar a sociologia da religião de Max Weber, Pierre Bourdieu argumenta que, em toda a sua vida, Weber se esforçou para provar a eficácia histórica das crenças religiosas, contrariando o reducionismo da teoria marxista".

Para Bourdieu (2004, p. 57) o campo é compreendido como o espaço social das relações de força, mais ou menos desiguais, em que os protagonistas, agentes dotados de um domínio prático do sistema, de esquemas de ação e de interpretação, se situam com posições bem demarcadas, levando consigo, em todo tempo e lugar, sua posição, presente e passada, na estrutura social sob a forma de babitus ${ }^{4}$. Tal perspectiva pode ser pensada a partir do viés interpretativo, no depoimento de uma das benzedeiras entrevistadas para a composição desta pesquisa: "Eu uso qualquer ramo pra benzê, mas não benzo de coisa forte, só de quebranto e mau-olhado. Aqui na creche tem muito disso, às vezes, as criancinha tá sonolenta ou não come direito, as menina chega e pede, eu cato um raminho ali mesmo e benzo as criança, elas fica boa, come, é uma maravilha" (ENTREVISTA COM DNA. CLEUZA, 16/09/2014).

Para Dna. Cleuza, cada pessoa que benze, lida com um tipo específico de mal (físico, moral, existencial, social, econômico) e constrói, portanto, um habitus em seu cotidiano ou uma estreita relação desse mal situado em seu sistema de crenças e em seu cotidiano, que chamaremos aqui de real, na esteira do pensamento de Bourdieu (1991).

Nesse sentido, para Pierre Bourdieu (1991, p. 114), o conceito de habitus é entendido como um "conjunto das disposições inconscientes que estariam presentes em diferentes sujeitos, levando-se em conta que tais disposições seriam o resultado da interiorização de complexas estruturas objetivas presentes numa sociedade".

De acordo com Bourdieu (2007, p. 34), o trabalho religioso é realizado por agentes especializados, porta-vozes institucionais poderosos, que respondem com um tipo de prática e discurso a um tipo de necessidade e a um grupo determinado.

4 Bourdieu pretende ao propor o conceito de habitus, eliminar do âmbito científico o distanciamento existente na sociologia de Weber entre indivíduo/sociedade. Desse modo, os fatos sociais só existem porque existem antes os indivíduos, de modo que, tal teoria se relaciona à capacidade de uma determinada estrutura social ser incorporada pelos agentes por meio de disposições para sentir, pensar e agir como procuro demonstrar no caso das benzedeiras que constituem seus fatos sociais ao mesmo tempo que os vivenciam no movimento que fazem entre as estruturas, medicina, cultura e religião (BOURDIEU, 1989; 1990; 1991; 1996). 
A esse respeito, afirma Oliveira (2003, p. 182) que no trabalho religioso reside a maior contribuição à sociologia da religião. Para ele, "há trabalho religioso quando seres humanos produzem e objetivam práticas ou discursos revestidos de sagrado, e assim, atendem a uma necessidade de expressão de um grupo ou classe social" (OLIVEIRA, 2003, p. 182).

Nesse mesmo viés, Dna. Adelícia demonstra em sua fala crer que fora escolhida, eleita pela Virgem Maria, dada a sua fé na Santa, para fazer o que considera como o bem, ressignificado no ato da benzeção, dando sentido ao cotidiano sofrido das pessoas do seu bairro. Dna. Adelícia seria uma legitimadora da cura e da fé, pois ouve diretamente as reclamações de seus 'pacientes', sem ter salas ou mesmo remuneração fixa para isso. Mulheres como ela, atuam diretamente no campo da salvação pessoal e atribuição de sentido à vida de quem as procura. Sobre a concorrência no campo religioso pelo poder.

As benzedeiras possuem uma resposta imediata, além de mediadoras do sagrado, diretamente ligadas aos elementos naturais da cura, gozam de grande respeito e consideração por parte de vizinhos, amigos, apreciadores de sua arte. Isso talvez explique, parcialmente, sua permanência até nossos dias, pois não há muitos limites aparentes em sua prática; conforme me confidenciou Dna. Adelicia, as benzedeiras "ouvem o problema e em seguida fazem uma oração, propõem um emplastro, um chá, um ritual” e o que chamam de graça, simplesmente acontece. Nesse sentido, a graça é e brota da ação humana, é o agir humano, afetivo em função do outro, ao acolher o outro, ao dar uma fala amiga para ele.

Conforme evidenciamos no caso de Dna. Adelícia, de acordo com Bartz (2007), os sistemas de interesse religioso estariam vinculados à situação social, visto que, nesse espaço, a mensagem religiosa tem conotação relevante para alguns grupos na forma de ação simbólica, fornecendo um sistema de justificativas de existência a uma determinada posição social.

De modo semelhante, dentro das especificidades do campo religioso, o que Dna. Adelícia faz é estabelecer relação com as pessoas do bairro. Pode ser dito como criação e manutenção de habitus, onde ela situa o que ela é para os demais.

Novamente citamos o comentador Bartz (2007) sobre o poder religioso, que é o produto de um negócio (transação) entre agentes religiosos e leigos, em que o interesse de cada categoria, deve ser contemplado, sendo que o poder que os agentes religiosos detêm, deriva do princípio de estrutura das relações de força simbólica, conforme desejo indicar ao citar o depoimento 
seguinte: "Com a reza de espinhela eu rezo pra várias coisa, mas vô mudando arguma palavra. Às veis eu peço pra um santo, ora pro otro, dependendo do que eu tô sentindo na hora. Cada oração sai de um jeito e o que importa é a gente tê aquela fé de que vai curá e cura mesmo" (ENTREVISTA COM DNA. CLEUZA, 16/09/2014).

Ao expor a fala de Dna. Cleuza, entende-se evidenciar que o poder religioso exercido pelas benzedeiras não é nem institucionalizado, nem formal, mas está presente desde sempre, possuindo raízes históricas milenares, talvez mais antigas que o próprio cristianismo. Assim, torna-se, no campo dos significados linguísticos de sua constituição, um campo religioso relativamente autônomo dentro do processo de incorporação de crenças populares que pode ser evidenciado na fala de Bourdieu (2007, p. 69).

É possível que em Bourdieu (2007, p. 57), a benzedeira possa ser pensada como um agente social da interação, pois como Dna. Cleuza ressaltou na entrevista, ela e as demais, atendem a todos, "sem olhar a quem" como ela mesma mencionou. Há que se distinguir, todavia, a prática da benzeção de práticas de feitiçaria ou de elementos ligados ao espiritismo, ainda de forma apriorística, embora se reconheça que aquela também pode ocorrer em tais variações.

Sobre os aspectos da condição religiosa, sete benzedeiras se declararam essencialmente católicas, sendo que dessas, cinco disseram participar com frequência de missas; uma disse não participar e outra declarou participar pouco. Sobre as outras três, duas se declararam espíritas e outra de prática candomblecista de mesa branca, sendo que ambas participam sempre de suas escolhas religiosas.

Segundo o que expressa a fala de uma delas: "Menino eu sou católica desde a minha mãe, nunca mudei, nunca fui in nada qui num fosse católico. Tenho força na igreja, mesmo na roça quando nois morava na fazenda paredão, eu rezava o terço duas treis veis no dia. Moro aqui tem 5 anos, tenho meus santos, minhas devoção e graça a deus minha casa sempre foi guardada" (ENTREVISTA SEBASTIANA, 11/09/2014).

No tocante às relações sincréticas, as duas benzedeiras espíritas disseram participar da igreja católica e duas das que se declararam católicas disseram ter participado do espiritismo por um tempo. Nenhuma disse frequentar denominações pentencostais, evangélicas ou protestantes, o que pode indicar forte influência do catolicismo em suas práticas. Dna. Dalila 
Um olhar sobre as benzedeiras do município de Quirinópolis: 131 entre a cultura, a religião e a medicina popular

mencionou que é muito procurada por evangélicas, por conta de uma garrafada que faz para mulheres engravidarem.

O aspecto sincrético parece desaparecer quando perguntado sobre a relação entre a religião professada e a prática realizada por elas, benzedeiras, dado que as católicas declararam que sua prática tem relação com sua religião, o mesmo aconteceu com as benzedeiras espíritas e com a candomblecista.

Conforme se abordou, todas as benzedeiras têm uma ligação com algum tipo de credo, confissão ou campo religioso. Tal prerrogativa liga-as, de alguma forma, ao que poderíamos chamar aqui de religião formal. Concomitantemente, sua aparente estabilidade econômica lhes confere, num contexto capitalista, condições de desenvolver sua prática. E é justamente nesse ponto que se pode inferir que ter família, esposo e certa condição econômica, também pode ser apontado como um fator de permanência social das benzedeiras e suas práticas em um cotidiano urbano e racionalizado de modo a dar sentido existencial a esse cotidiano, conforme ressaltou-se em Bourdieu (2007, p. 45).

Para Lemos (2010), a benzedeira utiliza-se do mito enquanto relato de um acontecimento ocorrido no tempo primordial, contando com uma tradição ancestral. A partir de Lemos, entende-se que as benzedeiras, incorporam a ideia de serem os agentes especialmente escolhidos pelo seu deus e entidades para manipular a força mágica, a magia, a sabedoria popular, que nem os médicos, nem os padres podem fazer. Não se veem como melhores, apenas com um dom específico. Em outras palavras, "o curandeiro é um membro das classes populares de cujo modo de vida e de pensamento, ele participa" (BOLTANSKI, 1989, p. 62).

No contexto de Boltanski, em concomitância ao que foi enunciado em Weber e Bourdieu, as benzedeiras estão inteiramente inseridas em seu contexto sócio-histórico, fazem aquilo que naturalmente aprenderam, em sua maioria, não frequentaram escola, nem cursos para serem benzedeiras. Em seu ofício, não só as orações faladas são fundamentais, mas os instrumentos como, por exemplo, a faca e a garrafa para benzer afta e dor de cabeça, que, unidos às rezas, permitem que essas realizem seu ofício sagrado de curar males do corpo e do espírito (SILVA, 2009), conforme se quer evidenciar no seguinte depoimento: "Aonde o bicho passeia fica o verme do cobrero. Então é só a reza que dá vorta. Já vi gente cum cobrero di tudo quanto é jeito e si num benze não sara. Já benzi até di amansar as cobras pra não ofender gente e os bicho. Como nois morava na roça e num tinha recursos, 
precisava aprendê, num tinha outro jeito" (ENTREVISTA COM DNA. SEBASTIANA, 11/09/2014).

Para Dna. Sebastiana existem situações em que a única forma de cura é por meio da reza e da oração, já que não há ali outro recurso. Conforme sinalizou-se com Silva (2009), o que se pode afirmar, é que Dna. Sebastiana é uma legítima agente da magia que crê portá-la e manipulá-la, vive disso e vive isso em seu cotidiano. Benzedeiras como ela, podem exercer qualquer outra função simbólica em sociedade, mas o 'ser benzedeira' parece ser a parte mais essencial e prazerosa de suas vidas.

O contexto da benzedura pode ser também entendido à luz do pensamento de Eliade (2002, p. 10). Para o autor, a questão do simbolismo, após o advento da psicanálise, ganhou proporções antes não esperadas. Dentre as revelações da nova ciência, encontram-se as percepções sobre o chamado 'pensamento primitivo' que o homem contemporâneo ainda carrega consigo. Poderia chamar tal fenômeno de mito, sonho, misticismo, mas em resumo, o fato é que mesmo avançando tecnologicamente, na medicina, nas ciências de um modo geral, a humanidade mantém certo sentimento bucólico sobre as forças do universo e suas influências, conforme se quer indicar comparativamente no depoimento abaixo:

Dia desses, veio uma moça e a mãe aqui trazendo um neném de cinco meses, enjuadinho, chorando e resmungando. Daí um pouco chegô a vez deu atendê elas e foi batendo o ôio eu reparei que a criança punha muito a mão na barriga quando se contorcia, ah mas falei logo, isso aí é caso de chá de Marcelinha, num é de benzimento não. Daí uns dia ela voltô e agradeceu porque o bebe num tinha mais nada e tava dormindo bem. (ENTREVISTA COM DNA. MARLY, 13/09/2014)

Como se pretende inferir, nem sempre o simbolismo é recobrado, dado que a percepção e a intuição (diagnóstico) das benzedeiras também assumem forma simbólica. De modo geral, a cultura do simbolismo se dá de maneira sincrônica em toda a Europa, nas formas exótica, evoluindo para a esotérica, e na forma arcaica, de maneira que o simbolismo se articula de modo variado, embora, sobre algumas desenvolturas, conserva elementos simbólicos antigos. No âmbito secular, observa-se isso, talvez por se modificar de acordo com algum modismo, transforma-se, mas sempre retorna e sempre retoma elementos antigos. 
Um olhar sobre as benzedeiras do município de Quirinópolis: 133 entre a cultura, a religião e a medicina popular

A ultrapassagem do 'cientificismo' na filosofia, o renascimento do interesse religioso depois da primeira guerra mundial, as múltiplas experiências poéticas e, sobretudo as experiências do "surrealismo" (com a descoberta do ocultismo, da literatura negra, do absurdo, etc.) chamaram, em planos diversos e com resultados desiguais, a atenção do grande público para o símbolo encarado como modo autônomo de conhecimento. (ELIADE, 2002, p. 10)

Assim, mesmo na América, continente relativamente novo e, considerando o contexto da pós-revolução industrial, os diversos mitos e culturas assumem essas variadas formas simbólicas. Em tal contexto, as benzedeiras podem ser apontadas como uma forma muito antiga de intervenção simbólica nos casos de saúde-doença como demonstrou-se no 'causo' relatado por Dna. Marly, anteriormente apresentado.

No tocante ao que se explicitou até aqui, as benzedeiras seriam, no contexto sul-americano (brasileiro e goiano), o resultado da falta de estrutura do novo continente e das relações burocráticas com tal continente. Por ser uma prática repleta de simbolismos, conforme fora exposto, torna-se fácil entender como tal figura transita entre aceitação e exclusão cultural, dado que na cultura, enquanto elemento simbólico cultivado por um grupo social maior ou menor, as benzedeiras transitam com certa facilidade, sendo que nas religiões formais, não teriam tanta facilidade.

Tais simbolismos assumem no cotidiano das rezas das benzedeiras, a forma de ontologias. Para Souza (2011, p. 206): "A ontologia religiosa, expressa em categorias arcaicas, não é exclusiva das sociedades primitivas: é condição do ser humano, o homo religiosus, representado nas culturas antigas". Nesse mesmo sentido, segundo Allen (1998), que analisa o conceito de religião em Eliade: "A ontologia religiosa é o movimento do indivíduo que busca ir além da História e integrar-se com as origens, a natureza e o cosmos; é condição do homo religiosus transcender a tudo que é material, finito, temporal e histórico; é a busca pela consciência espiritual da liberdade incondicional que está além do tempo, história e até do cosmos" (ALLEN, 1998, p. 220).

As formas simbólicas e, portanto, ontológicas construídas também na América Latina são uma característica tipicamente humana, não sendo uma manifestação necessária de irracionalidade, mas antes, de compreensão primitiva ou cultural dos fenômenos míticos e religiosos. Para Eliade (2002, p. 14): “o pensamento simbólico não é domínio exclusivo da criança, do poeta ou do desequilibrado: ele é consubstancial ao ser humano; precede a linguagem e a razão discursiva". 
Como foi dito, as imagens, os símbolos, os mitos, são a expressão da psiqué, são as formas possíveis de interpretação da realidade, que um ser ou um grupo têm de descrevê-la, sendo, portanto, uma substituição do real por algo simbólico, não que tal símbolo o represente fidedignamente. Desse modo:

Quando um ser historicamente condicionado, por exemplo, um ocidental dos nossos dias, se deixa invadir pela parte não histórica de si próprio (o que lhe acontece com muito mais frequência e muito mais radicalmente do que ele imagina), não é necessariamente para regredir ao estágio animal da humanidade, para tornar a descer às fontes mais profundas da vida orgânica: imensas vezes ele reintegra, pelas imagens e símbolos que põe em marcha, um estágio paradisíaco do homem primordial (seja como for a existência concreta daquele, pois este 'homem primordial' afirma-se, sobretudo como um arquétipo impossível de 'realizar' em qualquer existência humana). (ELIADE, 2002, p. 14)

Pode-se pensar a ideia de homem primordial (estado arquetípico), a partir do problema de um estado de integração do homem com a natureza, de modo que desaparecem os problemas de uma vida cotidiana repleta de situações trazidas pela modernidade a partir do século XVIII. A ideia de homem primordial remete a um tipo de indivíduo que consegue, na modernidade, manter-se em contato com as mais arcaicas tradições, e assim, manipular sua realidade cotidiana, a fim de dar-lhe significado, e permitir-se melhores condições de sobrevivência.

Nesse sentido, as benzedeiras como Dna. Marly, citada anteriormente, seriam essa aproximação de homem primordial, uma vez que fazem com que emerja a força da natureza e a aproximação do indivíduo massificado, estressado com tal realidade intra, supra ou extrassensível, já que tal realidade existe, mas que o indivíduo se encontra em um estado não simbólico de permanência nela, bem aquém de tal contexto.

Ao confrontar e dialogar diferentes tradições (como a arcaica e a ocidental, a popular e a oficial), o ser humano moderno deve incorporar preocupações existenciais em novos caminhos para que novas concepções míticas e religiosas possam existir e ter sentido, para então revelar e descobrir aspectos universais do espírito humano. (SOUZA, 2011, p. 11)

Tais aspectos universais não seriam justamente princípios norteadores do viver humano como a tranquilidade, a harmonia com o meio, a 
Um olhar sobre as benzedeiras do município de Quirinópolis: 135 entre a cultura, a religião e a medicina popular

manutenção dos estados de saúde. Para Eliade (2002) essas imagens são multivalentes, ou seja, possuem diversos e amplos sentidos, chamados por ele de "feixe de significados". Nesse sentido, entende-se que as benzedeiras estão inseridas culturalmente nesse feixe e são suas tramas simbólicas, suas tessituras que, de certa maneira, mantêm a procura dessas pelas classes sociais diversas. Como existem muitas delas, assim também existirão demandas variadas.

O homem moderno é livre de desprezar as mitologias e as teologias, mas isso não o impedirá de continuar a alimentar-se de mitos decadentes e de imagens degradadas. A mais terrível crise histórica do mundo moderno - a segunda guerra mundial e tudo o que ela desencadeou com e após ela demonstrou suficientemente que a extirpação dos mitos e dos símbolos é ilusória. (ELIADE, 2002, p. 19)

No que fora citado, Eliade (2002, p. 19) faz referência a um conjunto de significados relativos aos riscos da vida cotidiana e à ideia de perfeição paradisíaca: "As nostalgias são por vezes carregadas de significações que comprometem a própria situação do homem". Tal comprometimento se dá em relação ao processo de abandono do mito. No mesmo viés, conforme já apontou Weber (1982, p. 183): “A dessacralização ininterrupta do homem moderno alterou o conteúdo da sua vida espiritual, mas não quebrou as matrizes de sua imaginação".

Depois de tratar da relação ontológica dos simbolismos presentes na religiosidade e aplicar isso para o caso das benzedeiras, situo o caso das benzedeiras ainda no ditame da cultura como substrato de sua prática, na vertente dos processos culturais. Esses, por sua vez, são comuns a toda e qualquer população, grupo, entidade, clã ou segmento. Desse modo, podese inferir que o que confere unidade ao homem "[...] é a sua aptidão à variação cultural [...] aquilo que os seres humanos têm em comum é a sua capacidade para se diferenciar uns dos outros" (LAPLANTINE, 1988, p. 22). É justamente esta construção das diferenças que permite às benzedeiras, elaborar costumes, línguas, modos de conhecimento, instituições, jogos profundamente diversos. Portanto, ser capaz de se diferenciar o que é natural e o que é abstrato no homem.

Nessa mesma menção, a figura das benzedeiras continua a obter respaldo nos processos culturais de assimilação - processo pelo qual pessoas ou grupos de pessoas adquirem características culturais de outros grupos sociais - , difusão 
- processo pelo qual duas ou mais culturas diferentes, entrando em contato contínuo, originam mudanças importantes em uma delas ou em ambas -, enculturação -influência mútua entre o cristianismo e as culturas dos países em que a fé cristã é praticada-, aculturação - processo de modificação cultural de indivíduo, grupo ou povo que se adapta a outra cultura ou dela retira traços significativos -, endoculturação -processo permanente de aprendizagem de uma cultura que se inicia com assimilação de valores e experiências a partir do nascimento de um indivíduo e que se completa com a morte (MARCONI; PRESOTTO, 1989, p. 60).

Dentro do exposto sobre os processos culturais, situa-se que as benzedeiras e seu simbolismo de curas, bênçãos e banhos rituais possuem interessados e pessoas que culturalmente lhes atribuem crédito e fé, dado que o homem pode ter abandonado os mitos antigos, mas continua a alimentar uma ideia mitológica do mundo, ideia essa que é apenas substituída por uma nova, igualmente simbólica, igualmente mítica, mesmo que racionalizada.

No que fora apontado por Marconi e Presotto (1989), as benzedeiras são entes culturais que difundem sua cultura, assimilam novas práticas, penetram em culturas tanto arcaicas como novas, resguardam sua tradição e transitam livremente em sua própria cultura.

Ainda sobre os processos culturais, dentre os símbolos que o homem constrói do mundo, está o do centro. O autor Eliade (2002, p. 39) destaca o simbolismo do centro, dado que todo local habitado tem um centro. Trata-se de uma assimilação entre o indivíduo e o que para ele é importante, assim, as cidades têm um centro comercial, uma praça central, um marco zero, algo que simbolize a origem ou um elemento considerado 'mais importante'. No caso das benzedeiras, esse centro está no quintal, no oratório, nas plantas e ervas que elas utilizam em sua prática, dado que podem atender em qualquer lugar de sua casa. Trago o depoimento abaixo, como expressão dessa ideia de centro que Eliade acaba de indicar:

Já usei arruda, alecrim, alfavaca, comigo-ninguém-pode, espada-de-são-jorge, alfazema, folha de fortuna, catinga de mulata. Uai qué vê, a erva cidreira é boa pra tosse e febre; gervão que só vi no mato grosso cura tosse e machucado; bálsamo é pra problema de fígado e a babosa também, uso ela pra morroida tem veis; o capim da folha santa é bom pra dor de cabeça e já a arruda pra dor de estômago. Tem demais, cada uma pra um poblema (ENTREVISTA COM DNA. JOANA D'ARC, 07/10/2014). 
Um olhar sobre as benzedeiras do municipio de Quirinópolis: 137 entre a cultura, a religião e a medicina popular

Para Dna. Joana, uma das entrevistadas desta pesquisa, as ervas são importantes elementos de cura, são o centro de sua prática, todavia, falando geograficamente, as casas das benzedeiras não são geralmente casas no centro das cidades, ao contrário, em geral, estão nas periferias ou vilas, pois são símbolo dos menos favorecidos, não são pessoas em condições financeiras muito elevadas. Mesmo assim, suas casas estão situadas dentro do que Eliade (2002, p. 42) chama de "zonas cósmicas", ou seja, "Céu, Terra e inferno". Pelo uso das ervas, as benzedeiras assimilam a cultura local com seus usos e costumes, revestem seu espaço do lar de um simbolismo do centro, criam zonas cósmicas.

As casas das benzedeiras como Dna. Joana, possuem ainda um imago mundi, um local específico eleito por elas, aparentemente de forma intuitiva, em que situam a cadeira ou mureta onde o benzido se assenta, quase sempre de costas para a casa. Esse local varia de acordo com o tipo de oração e mal a ser tratado. Em casos de pragas, infestações, câncer, a oração é feita no espaço fora da casa, no quintal. Em casos mais leves como mau olhado e quebranto, as benzeções podem ser feitas na varanda das casas. Casos como o de tratamento do mal de simioto são feitos dentro da casa, pois a criança fica sem blusa e pode se resfriar.

Também o mito da árvore primordial que se repete na oliveira para Israel, a árvore da vida para o Éden, está presente no tipo de ramo utilizado no chá ou benzedura. "A comunicação entre o Céu e a Terra torna-se possível por meio desse pilar. E, de fato, o sacrificador sobe ao Céu, só ou com a mulher, neste poste transformado ritualmente no próprio 'Eixo do Mundo"' (ELIADE, 2002, p. 44).

Assim como o simbolismo do 'Centro', outro simbolismo que pode ser aplicado ao caso das benzedeiras é o dos nós e do ato de desfazer tais nós, lembrando que todos esses processos culturais acontecem dentro do âmbito da assimilação cultural.

Em tal contexto, os nós seriam pontos que mesmo a acupuntura revela em seu simbolismo. Entraves, problemas, doenças em partes do corpo, tudo isso seriam nós que devem ser desfeitos. No contexto católico, pode-se citar a figura de Nossa Senhora Desatadora dos nós, a qual foi apontada por Dna. Joana como sua protetora particular. Assim, os nós assumem forte simbolismo de vida e de morte, de saúde e de doença. "Os nós provocam a doença, mas também a afastam ou curam o doente; as 
redes e os nós enfeitiçam e também protegem contra a feitiçaria; impedem o parto e facilitam-no" (ELIADE, 2002, p. 109).

Nesse caso o depoimento abaixo indica alguns desses nós que, segundo a crença, assumem grande influência no cotidiano sociocultural das pessoas: "O que as mãe mais procura é de quebrante e espinhela, às veis as criancinha tá injuada e não é dente nem nada, daí eu benzo de espinhela, pode dar até diarreia e vômito. Tem criança já grande que tem que Benzê duas veis, a noite e no outro dia. Outro dia veio um senhor aqui pra benzer e a filha dele é inté enfermeira" (ENTREVISTA COM DNA. VALDIVINA, 22/07/2014).

Aqui se acrescenta que desatar os nós tem relação com certa tomada de consciência dos problemas cotidianos, ou ainda com sua causa-origem.

Semelhante ao que fez o teólogo protestante alemão e erudito em religiões comparadas Rudolf Otto (2007) em O Sagrado, quando situa o problema da manifestação religiosa no que chama de numinoso, tremendum, totalmente transcendente, Eliade (2001) pensa o sagrado na condição de uma manifestação exterior ao homem por ele mesmo, por um olhar que seja diferenciado do que teria em relação a outros objetos e situações, trata-se de um fenômeno.

Assim, o sagrado seria qualquer coisa natural e não sobrenatural, que seja vista de uma maneira diferente do dito normal. "O Cosmos, na sua totalidade, pode tornar-se uma hierofania'. No fundo há toda uma proximidade entre Otto (2004) e Eliade (2001), dado que o que determina em ambos o sagrado, o numinoso, a hierofania é justamente a maneira como se vê o fenômeno. "Manifestando o sagrado, um objeto qualquer se torna outra coisa e, contudo, continua a ser ele mesmo, porque continua a participar do meio cósmico envolvente" (ELIADE, 2001, p. 13).

Para as sociedades primordiais, quanto mais primitivas suas condições de vida, maiores são as condições de poder, e menor é a percepção do humano, do homem, e maior a percepção de um mundo mais aterrorizante que o do ser humano em si, conforme ressaltou Dna. Joana: "O mundo tem muita coisa ruim meu fio".

Se a percepção do mundo constitui a ideia de que esse é sagrado por ser criação de Deus, o mundo biológico e o físico seriam assim também. Mas, ao mesmo tempo que é sagrado, é desconhecido, e, portanto, profano; de modo que se remete a uma percepção universal de que existe um todo (o universo, o cosmos) que é sagrado, e uma realidade particular (a terra, o cotidiano) que é profana. "A oposição sagrado/profano traduz-se muitas vezes 
Um olhar sobre as benzedeiras do município de Quirinópolis: 139 entre a cultura, a religião e a medicina popular

como uma oposição entre real e irreal ou pseudorreal" (ELIADE, 2001, p. 14), nesse caso, entre o conhecido e o desconhecido.

De acordo com Dna. Valdivina, o mundo é bom e mau, sagrado e profano, cabe a cada um escolher, colher no mundo aquilo que quer. Como ela mesma me disse: "Eu no quintal filho, posso escolher pegar cebolinha verde pra fazê o armoço" (ENTREVISTA COM D. VALDIVINA, 22/07/2014).

As benzedeiras estariam simbolicamente em intensa relação com o sagrado e o profano, lidam e operam nos dois mundos, extirpam o mal e clamam pelo bem. Recriam o mundo, remontam as hierofanias e as teofanias, de modo que buscam fazer prevalecer o bem sobre o mal. O espaço residencial da benzedeira é, portanto, um espaço tido como sagrado, sendo que ali, manipula-se o profano, a força negativa do mundo presente no reclamante ou por ele transportado/acusado. É essa capacidade que confere significado à prática das benzedeiras e as tornam socialmente aceitas.

O simbolismo do caos e cosmos pode muito bem ser aplicado à percepção anterior no sentido de que a vida, por si só, é caótica, dado ser estressante, corrida, cansativa e repleta de heterogeneidades; desse modo, a benzedeira promove a ordem, o reordenamento da vida, do mundo, do cosmos por meio de uma oração, de uma benção, ativando assim uma nova perspectiva, uma nova ordem na mente e, portanto, na vida do reclamante, conforme expressa o depoimento a seguir: "Já benzi até fazenda. Coisa di homi né, mas benzi. As galinha tava intizicada, muito pior e eu fui lá mais meu marido e nóis pegô firme. Falei pra ele rezá comigo que aqui só dois pra dá vorta” (ENTREVISTA DNA. SEBASTIANA, 11/09/2014).

De mesmo modo, os 'ritos de passagem' representam a mesma reorientação do homem no mundo profano, enquanto postura sagrada. Para os cristãos, os sacramentos representam um rito de passagem, em que o antes pagão, agora no batismo, torna-se cristão; o sexo antes pagão, no casamento, torna-se elemento de santificação. O passe, banho ritual, benção ou benzeção refletem uma rotura, uma brecha, uma separação entre o antes e o depois da hierofania (ELIADE, 2001).

O rito de passagem é marcado, portanto, por uma festa, cerimônia, benzeção, encontro ou visita; todos esses, com significado mágico. O batismo, o casamento, a unção, o festejo, a visita à benzedeira, enfim, o momento em que, simbolicamente, abandona-se uma postura e se inicia outra. Depois de um dia estressante, o homem chega à casa, retira a roupa suja, suada, e com ela, simbolicamente seu cansaço; entra na água que é um dos muitos elementos hierofânicos e depois sai do banho, limpo, renovado; aquele foi 
para ele, um rito de passagem, pelo menos é o que expressa Dna. Joana em seu depoimento abaixo:

As pessoa aqui me considera muito; sabe que eu benzo e me respeita; todo dia tem uma me chamano pra comê pão de quejo e bebê café. As vez vem gente de longe, lá do Santa Clara e pedi pra eu benzê e eu benzo. Desde pequena minha mãe sempre levava meus irmão e eu pra benzer. Se um de nois ficava sem comer, ela levava nois tudo ela levava pra benzer. Eu entende-se muito na benzeção, se a gente tem fé a cura acontece. (ENTREVISTA COM DNA. JOANA D'ARC, 07/10/2014)

O posicionamento de Dna. Joana, a pintura de uma casa, uma reforma, um móvel novo, a mudança de casa, de emprego, de cidade, de carro, de bairro, tudo isso implica em uma mudança de hierofania, o homem religioso precisará adotar novos ritos para sacralizar seu local existencial. Ao estudar para um concurso ou prova importante, acenderá velas, fará orações, ficará mais introspectivo. Ao entrar em um jogo fará um sinal sacralizando seu local existencial.

Do ponto de vista da inserção cultural, a benzeção foi multidisseminada. Conforme Lemos (2009), a prática da benzeção é bem mais antiga do que os registros mostram, sendo ainda mais comum, nos meios em que tenham aflorado formas aqui descritas de catolicismo e religiosidade popular. Também muito variadas são as razões para se buscar o auxílio de uma benzedeira, sendo que as doenças são a principal delas.

Nesse contexto, há de se perceber uma relação direta entre o papel exercido pelas benzedeiras e as questões de saúde já evidenciadas, o que, necessariamente, difere-as da prática institucionalizada católica que envolve missa e sacramentos, à exceção, da unção dos enfermos que também apresenta uma relação com os estados de saúde-doença-morte.

Tal constatação também traz à tona um segundo elemento de incorporação das benzedeiras que é a relação por último descrita. É possível que os pedidos das benzedeiras no Brasil fossem inicialmente relacionados a pestes, chuva, sucesso profissional, ao contrário da raiz histórica de onde surgiram. Um terceiro ponto é o da questão teológica da prece amplamente exposta nas rezas citadas nesta pesquisa.

Não há nenhuma preocupação com fidelidade às verdades teológicas, ao contrário, às vezes o conteúdo dos benzimentos não parece ter nenhum sentido teológico ou mesmo seguir alguma lógica científica ou de linguagem. 
Um olhar sobre as benzedeiras do municipio de Quirinópolis: 141 entre a cultura, a religião e a medicina popular

O importante é o caráter sagrado que se dá às palavras e fórmulas que são pronunciadas (LEMOS, 2007, p. 4).

As benzedeiras entrevistadas respondem imediatamente ao problema, não consultam primeiro as entidades para depois dar a resposta, ao contrário, ouvem a queixa e logo em seguida propõem a oração, impõem a mão ou o ramo, e agem como quem extirpa ali mesmo o mal. Para Lemos (2007, p. 4) "os ritos não são reações espontâneas a situações de perigo, mas representações dessas reações, institucionalizada". O depoimento a seguir parece indicar esse instantâneo: "Pra benzê é simpre, num sei proque as pessoa nova num aprende. Ocê pega ua foia verde, um ramim, e vai na perna o no braço, onde tivé a dor e reza: Deus te fez, Deus te criô, de Deus te ingerô. Tirai esse mal qui nocê entrô. Vai pras montanhas pa nunca mais vortá. Cum os puderes de Deus da Virge Maria sereis cortada" (ENTREVISTA COM DNA. ADELICIA, 02/09/2014).

Mesmo sendo imediato o atendimento, a benzedeira mantém em sua memória um rol de possibilidades de benzeção; não há uma ritualidade institucionalizada como se percebe, por exemplo, no rito de uma missa, em que se tem um momento para cada rito, ao contrário, o que fora 'bento' hoje de uma maneira, pode receber uma oração diferente amanhã, conforme a conversa que se tem antes com o reclamante.

Assim, entende-se que a relação entre as práticas das benzedeiras e o catolicismo, em sua forma popular, é bem mais intrínseca que se possa pensar, pois permeiam nosso cotidiano desde as primeiras manifestações humanas no mundo.

Dentro do que fora exposto como pesquisa empírica, nota-se que a respeito dos aspectos da religiosidade popular das benzedeiras entrevistadas, foram propostas 15 questões abertas, que depois foram reunidas para fim desta análise. No afã de buscar mapear isso, passo a expor o que fora colhido com tais questões em semelhança e aproximação ao que se tratou neste artigo.

Em relação ao santo de devoção das benzedeiras entrevistadas, seis delas disseram ter um apreço especial por Nossa Senhora D'Aparecida, sendo essa a santa mais recorrente. Depois, cita-se A trindade ou Divino Pai Eterno, Rita de Cássia; São José aparece duas vezes, Medalha milagrosa uma vez, e a benzedeira candomblecista conta ainda sobre os guias e uma entidade que chama de Zé Pilinho ${ }^{5}$.

Zé Pelin, Pelinho ou Pelintra é uma entidade originaria do Catimbó nordestino e comumente incorporado em terreiros de Umbanda e Candomblé, tendo seu culto difundido em todo o Brasil e no Mundo. 
Conforme se indicou, a maioria só benze em casa ou no local de trabalho que é de atendimento a crianças. Não há uma classe social específica que procure a prática da benzeção como já se mencionou, todas declararam já terem atendido pessoas das mais variadas classes sociais. A maioria das benzedeiras entrevistadas recebeu o ofício de benzer da mãe, avó ou pai e avô, não respectivamente, mas uma benzedeira indicou ter aprendido com a tia e outra com outra benzedeira, sua vizinha, conforme o depoimento abaixo:

Uai, aprendi a benzer com meu avô e minha mãe. Meu avô principalmente era benzedeiro afamado. Benzia de tudo também. Eu oiava aqui di pequena e fui crescendo e vendo ele ajudá os outros. Quando casei comecei a criá corage. No começo eu ia escrevendo no papel, depois ia decorando as reza e fazendo. Eu tinha umas boneca lá guardada quando di criança e eu já benzi até eza. Tem mal que os médico não vê e a benzedeira vê. (ENTREVISTA COM DNA. SEBASTIANA, 11/09/2014)

Perguntamos qual seria, na visão delas, a importância dessa prática para a comunidade, e embora as respostas fossem variadas, todas admitiram que tal importância é grande, muito importante, de muita ajuda e valorizada pelos que possuem fé; trata-se de um serviço ao próximo.

Foi questionado também sobre a prática religiosa das benzedeiras em relação ao que sentiam durante a reza, as incidências foram: fraqueza, bocejo, tonteira, sono e moleza, arrepio e tontura, sonolência e cabeça longe. Duas disseram nada sentir e uma relatou sentir uma força que chamou de 'diferente' sem saber explicar. De acordo com uma das benzedeiras entrevistadas. "Eu benzo em qualquer lugar, porque é criancinha né, ai num tem perigo, mas no quintal é melhor porque às vezes eu pego um raminho, daí já deixo ali mesmo com o mato seco. Direto vem, hoje mesmo veio três menina pedi pra benzê, eu acho elas muito novinha hoje, sem experiênça" (ENTREVISTA COM DNA. VALDIVINA, 22/07/2014).

Dentro do exposto no comentário de Dna. Valdivina, a maioria das entrevistadas declarou ter benzido seus filhos quando pequenos e três disseram que por terem aprendido tarde o ofício, usaram os poderes da reza nos netos também, de modo que a família usufruía das práticas de benzeção e não só os reclamantes.

Sobre se ensinam o ofício a outrem, duas disseram que hoje as pessoas não querem aprender, sete disseram não ter ensinado e uma disse já ter ensinado umas dez pessoas benzer, inclusive as filhas. 
Um olhar sobre as benzedeiras do municipio de Quirinópolis: 143 entre a cultura, a religião e a medicina popular

Questionadas sobre se já teriam sofrido algum tipo de perseguição por serem benzedeiras, questão recorrente em alguns estudos analisados na pesquisa bibliográfica, nenhuma delas disse ter sofrido assédio religioso ou discriminação e uma ainda acrescentou: "Teve gente evangélico que me procurô e recomendô. A té da congregação. Queriam uma garrafada que eu faço pra engravidá. Já engravidou mais de três com ela. É tiro e queda" (ENTREVISTA COM DNA. DALILA, 06/07/2014). Noutro depoimento de Dna. Dalila, pode-se acompanhar: "Meu pai era médico prático, Meu avô e avó eram benzedores. Tinha muita sabedoria das planta. Minha irmã que me ensinô a mexer com planta, raiz e a fazer as orações. Já tive muito problema com minha família por causa das orações, eles não tinha paciência de esperar pra almoçar" (ENTREVISTA COM DNA. DALILA, 06/07/2014).

Perguntamos ainda se alguma delas evita algum contato físico com o reclamante (abraços, apertos de mão) depois da oração, ao que uma respondeu positivamente e outra disse que apenas toca ou pega no colo crianças novas, as demais disseram não tocar nos ditos reclamantes.

Ainda dentro do quesito aspectos da religiosidade popular, houve outras duas unanimidades, além da questão da perseguição. A primeira sobre se a procura por benzimentos se dá mais por pessoas de baixa renda e todas disseram que não, a outra questão foi sobre se elas consideram a própria casa um espaço sagrado e todas foram assertivas dentro dessa questão.

Perguntamos se elas viam algum tipo de relação de sua casa e sua prática religiosa, uma não soube responder, cinco disseram que sim e duas atribuíram tal pergunta ao fato de terem muitos santos (imagens) em casa. Uma disse que somente benze no quintal de casa. Duas das entrevistadas disseram que são procuradas por pessoas de religião não católica para exercer seu ofício.

As informações coletadas e expostas, apontam para uma prática e forma popular de religiosidade integradora de elementos culturais.

Conforme já expusemos, a ideia de que a medicina popular seria uma prática de ignorantes, destinada apenas aos pobres, seria, por demais, preconceituosa e inverídica. Poder-se-ia entender, nesse sentido, que as pessoas que procuram a medicina popular, fazem-no por desconhecer a medicina oficial, de modo que o inverso, também poderia ser contrariado, ou seja, quem procura pela medicina oficial, desconheceria parcial ou completamente a medicina popular, o que nos levaria a crer que esta tenderia ao seu fim, à medida que ocorresse o avanço daquela. 
Fato é que até os dias atuais, pessoas, famílias e profissionais da cultura popular conseguem manter certa autonomia, uma vez que a explicação para tal perspectiva se torna extremamente complexa e digna de estudo, não sendo, contudo, o escopo desta pesquisa. Novamente para Oliveira: "Ao proliferar suas práticas de cura e ampliar o conjunto de pessoas que se beneficiam com ela, a medicina popular acaba por acomodar algumas tensões sociais que resultam do modo como se oferece a medicina formal [oficial] em nossa sociedade. A medicina popular é uma forma de curar de baixo custo e fácil acesso" (OLIVEIRA, 1985, p. 14).

Conforme o citado, Dna. Marieta mencionou em sua entrevista que não tem nem dia nem tempo certo para benzer ou para os reclamantes chegarem, ou seja, está predisposta às necessidades sociais que surgem. Nesse sentido, pode-se pensar que a prática da medicina popular é um fenômeno religioso complexo, pois envolve não só elementos naturais, como também uma realidade social mais ou menos estabelecida com concomitâncias socioculturais bastante peculiares e dignas de uma maior investigação, dado poder estar aí a justificativa da propagação da crença na eficácia do trabalho das benzedeiras, como Dna. Marieta.

A medicina popular pode ainda ser pensada historicamente como uma identificação xamânica e, portanto, tribal. Pode ser relacionada com a imagem dos pajés, curandeiros, raizeiros e benzedores, conforme se apontou anteriormente. Dna. Marieta faz questão de mostrar que sua prática se liga à natureza, assim como culturas populares em que se originaram a medicina popular, sejam elas primitivas, naturalistas, rurais.

Assim como as festas populares, a medicina caseira era um elemento de construção e reafirmação cultural muito forte. Muitas vezes simultânea às rezas dos santos católicos, nas ladainhas, bênçãos, banhos de defuntos em preparações de velórios, a medicina popular, no processo de migração do campo para as vilas e cidades, passou a incorporar mais elementos religiosos ao contexto cultural e popular (OLIVEIRA, 1985).

Sete das dez benzedeiras entrevistadas admitiram já terem curado ou ajudado alguém desenganado pela medicina formal. Dentro desse escopo, pode-se citar o depoimento de uma das entrevistadas que afirma: "Tem coisa que é do médico curá mesmo, operá, cortá, costurá é o médico que faz; quando é coisa pequena, aí é a benzedeira. Tem gente que vai no médico, o médico faz tudo o que é exame, não acha nada, aí vem aqui e eu digo que só 
pode ser coisa do espirto nosso isso aí, daí pouco tempo a pessoa é curada" (ENTREVISTA COM DNA. DALILA, 06/07/2014).

A cura de desenganados é extremamente válida no tocante a confirmar a verdade da bênção e a positivação dos efeitos dessa. Noutro depoimento se lê: "Uai, meu sobrinho estava desenganado com uma dor, foi dado até por morto, ia num e nada, ia noutro e nada, acho que teve até no outro mundo e voltô. Rezei uma, rezei duas até que ele começô a melhorá. Era chá, folha macerada, fiz de tudo pra podê ajudá e ele melhorô. No fim era hérnia" (ENTREVISTA COM DNA. ALGENIRIA, 16/09/2014).

Ambos os comentários, revelam a forte crença no ofício de benzer e curar, mesmo que parcialmente, o enfermo. As benzedeiras entrevistadas e a literatura consultada até aqui, dão conta de que a medicina formal tem claro seu valor, mas a popular também o tem. As benzedeiras entrevistadas se mostraram cientes disso, que vou chamar de duplicidade da cura.

Sobre a pergunta dos tipos de doenças que podem ser curadas pela benzeção, o cobreiro apareceu em três apontamentos, o quebranto em sete, a espinhela caída em três, mau olhado em cinco. Males relacionados às funções neurológicas ou psicológicas como insônia, labirintite e dor de cabeça tiveram um apontamento cada. A esse respeito convém citar a seguinte fala: "Já curei até labirintite e o sinhô num é capaz de adivinhá com o quê? tabessero de paia de milho. Foi uma velha índia matupá que ensinou pra minha avó. Basta dormi nele algumas noites que a labirintite nunca mais vorta" (ENTREVISTA COM DNA. MARIETA, 14/09/2014).

Depois pedimos que as benzedeiras me apontassem as doenças mais comuns que chegam a elas; o quebranto teve quatro indicações; duas apontaram ser as doenças espirituais, uma apontou para a espinhela, e outra para a inveja, houve ainda um apontamento para o mal de simioto.

Em relação ao local escolhido ou utilizado por elas para fazer as rezas, como já se fez menção, apenas duas disseram que benzem em qualquer lugar da casa, mas a maioria prefere benzer no quintal ou areazinha coberta, e uma disse que benze na sala ou quintal. Essa pergunta permite avaliar qual é a relação que as benzedeiras fazem entre Bem e Mal e dessas com sua prática e residência. Os resultados apontados permitem entrever que a benzeção para as entrevistadas é uma prática que varre, expulsa o mal dos reclamantes e que esse pode ficar em sua casa, por isso benzer fora de casa é, consensualmente, preferencial pelas benzedeiras. 
Sobre qual era na opinião delas o mal mais difícil de extirpar, foram apontados: espirituais, simioto, erisipela, cobreiro bravo, falta de fé, descrença espiritual e o câncer. Tais respostas apontam estreita relação feita por algumas entre a prática da benzeção e o universo espiritual dos reclamantes. Tais males podem indicar relações com doenças viróticas, bacterianas, fúngicas, cujo tratamento exige remédios bem mais fortes e específicos, mas, ainda que seja buscada, por parte dos reclamantes a medicina convencional, esses não abrem mão dos cuidados das benzedeiras conforme elas mesmas reforçam em seu discurso.

Sobre quais plantas são mais comumente utilizadas para a prática ritual, foram ditas: arruda, todo tipo, guiné e arruda, arruda, barro, pedra, árvore, guiné e mirra, pé-de-perdiz, algodão branco e velasco, qualquer ramo, alecrim, poejo, hortelã e boldo. Uma benzedeira disse que não usa nenhum tipo de planta em sua prática, mas admite já ter feito uso de medicações naturais tais como chás. Segundo apontou uma das benzedeiras:

Tenho muitas ervas plantadas em casa, sempre tive. Quando não do pros que vem buscá eu mesmo uso, faço xarope, chá e tudo. A erva Santa Bárbara dizem tê o poder de levar relâmpagos e trovão pra longe e às vezes eu invoco São Jerônimo que protege contra chuva e da morte; Pego muito com os santo também. Nossa Senhora da Abadia, que é nossa padroeira, que eles falam protege contra ventania e Nossa Senhora do Perpétuo Socorro protege contra coisa ruim. Às vezes se é doença de pele eu peço pra mãe rezar pra São Lázaro que trata das doenças na pele (ENTREVISTA COM CNA. VALDIVINA, 22/07/2014).

Uma questão parecida foi sobre o uso das plantas como medicamento, ou seja, quais as benzedeiras as consideram mais importantes. Uma das benzedeiras disse que não considera nem usa as plantas em sua prática; outra disse que sendo ramo, basta, nesse caso ela está se referindo a ramos medicinais. Os apontados foram: marcelinha, manjerona, hortelã, poejo, mentrasto e alecrim, arruda, vassourinha, árvores, pois puxam o mal nosso. Outra das entrevistadas disse que todas as plantas são importantes. Essa pergunta, diferente da anterior, foi proposta dado que muitas das plantas, segundo as próprias benzedeiras, estão desaparecendo. Das entrevistadas, apenas três possuíam boa variedade de plantas de uso medicinal em casa.

Outro dado relevante foi a quase unanimidade das benzedeiras em relação à pergunta sobre se elas fazem garrafada. Apenas uma faz e as demais 
Um olhar sobre as benzedeiras do municipio de Quirinópolis: 147 entre a cultura, a religião e a medicina popular

manifestaram repulsa à prática, mas não foi possível medir o porquê, embora algumas tenham apontado que fora devido ao desaparecimento de certas plantas, conforme se mencionou antes.

Sobre os tipos de remédios caseiros que elas fazem uso em seu cotidiano, quatro disseram não fazerem uso, três disseram tomarem chás com frequência, uma apontou que toma a água da berinjela para controlar diabetes e outra toma o chá da hortelã apenas, para gastrite.

Sobre quais as situações em que recomendam os remédios caseiros, duas disseram não recomendar, duas não souberam responder, duas disseram que para todo tipo de mal recomendam tais remédios, uma disse que para tudo e outra recomenda remédios fitoterápicos para diabetes e colesterol.

A respeito da relação entre benzeção e medicina formal, questionei como elas viam a atuação das agentes de saúde da prefeitura, e nessa pergunta embuti uma discussão sobre a saúde formal. Elas foram unânimes em considerar que a presença dos agentes ajuda na saúde, embora uma tenha apontado que tais agentes nunca foram a sua casa e ela não sabe dizer o porquê. Todas veem a medicina formal como uma coisa boa dada por Deus ao homem, assim como a benzeção, mas uma indicou que a medicina hoje é praticada sem amor.

Conforme se pode observar no depoimento a seguir: "Eu entende-se no tratamento do médico, creditu que o remédio pode resolvê. Mas precisa de fé né, sem essa num tem santo que dê vorta. Então eu não só entende-se como pricisei de uma rezadeira e fui atendida na hora. Eu entende-se bastante na força da fé" (ENTREVISTA COM DNA. DALILA, 06/07/2014). Para Dna. Dalila, a medicina formal tem sim seu valor e deve ser explorado e respeitado. Esse outro comentário, de outra entrevistada, parece coadunar com o de Dna. Dalila: "Deus deixou o médico, deu a sabedoria pra ele podê curá as pessoas. Mas às veis a pessoa precisa que num é no corpo pra depois curá o corpo. Se eu vê que num consigo ajudá uma pessoa só com reza, eu mando ela procurá o médico e peço pra voltar depois e contar como foi" (ENTREVISTA COM DNA. MARIETA, 14/09/2014).

Perguntamos ainda como elas veem os médicos hoje, algumas indicaram que os médicos estão muito preocupados com eles mesmos, seus ganhos, soberba, e apenas duas os veem como bons.

Foi perguntado se existe para as benzedeiras diferença entre tratamento médico e o realizado pelo (a) benzedeiro (a), todas admitiram tal diferença, não havendo equiparação por elas em relação a sua prática e a da medicina formal. 
Em média, as benzedeiras atendem por semana 20 a 25 pessoas entre bebês, crianças, adultos e idosos, não havendo indicações de tal prática ser aplicada a jovens, seja por sua natural descrença, seja por sua rebeldia. Mesmo quando provocadas em relação às drogas, elas afirmaram que a reza não pode ajudar muito os jovens viciados. Mas duas reconheceram que ajudaram adultos alcoólatras. A benzedeira que atende menos pessoas por semana, atende três pessoas, a que atende mais, atende em média 90 pessoas por semana.

Sobre a pergunta se atendem mais mulheres ou homens, algumas disseram não atenderem homens adultos, apenas crianças de ambos os sexos; cinco disseram atender ambos sem problema e outra mencionou preferir o atendimento apenas às mulheres. Nesse caso, parece que ajudar, atender logo é o que mais permeia a prática das benzedeiras, conforme o depoimento abaixo:

Aqui se chega gente, eu procuro atendê na hora. Às veis desligo a panela e venho, notras meu marido tá aqui, ele ajuda. Atendo muita gente no ruim menino, aí é só benzê que melhora. Teve uma veis um menino na hora de benzê desmaiô. Benzi, dei um chá ai ele melhorô. Outra veis foi uma menina novinha que tinha medo de tudo, benzi e nunca mais vi, dicerto sarô o medo né. Eu num tenho medo di nada não, enquanto eu tivé as força de Deus tudo vai dá certo né (ENTREVISTA COM DNA. ADELICIA, 02/09/2014).

Para Dna. Adelícia, que atende homens e mulheres adultos, é essencial estar disponível quando é procurada, pois tem males que não podem passar da hora segundo ela, se não, depois são difíceis de extirpar.

Desse modo encerra-se a análise dos dados aqui proposta, relacionada ao tema saúde-doença-benzeção. Tal análise constitui um breve recorte do conjunto desta pesquisa, a qual prescruta alguns dos muitos mistérios (forças cotidianas, mas inconscientes) e hierofanias, do mundo das benzedeiras. Assim, esta pesquisa buscou relacionar tais mistérios às condições de sedimentação da prática da benzeção no contexto da cultura, religião e medicina populares. Entende-se que os resultados apontados indicam práticas rituais diretamente situadas no campo da tradição, crença popular, rituais primitivos e cura, poder das rezas, com especial atenção à evocação das forças da natureza.

\section{Considerações finais}

Aquelas que nesse estudo chamamos de 'as benzedeiras', são figuras simbólico-concretas, mulheres em geral casadas, que disseram que, em algum momento da vida, receberam o dom da benzeção. 
Um olhar sobre as benzedeiras do municipio de Quirinópolis: 149 entre a cultura, a religião e a medicina popular

Nos quatro elementos, na natureza de um modo geral, na evocação de um deus, de um santo, de uma entidade, na sabedoria passada de pessoas para pessoas e em muitas outras fontes, posso dizer que: ELAS BENZEM!, elas, as benzedeiras, mulheres que creem ter recebido divinamente esse dom, pedem, rezam, receitam, fazem seus chás e emplastros, ministram a cura, sem sofrer maiores intervenções por parte de médicos, religiosos ou cientistas. Posso dizer também que: AS PESSOAS VÊM! De todos os lugares, classes sociais, cidades. Elas ligam, pedem orações, gratificam e seguem sua vida até que seus filhos ou netos voltem a prescindir das benzedeiras.

De vários modos a mulher se sobressaiu na história, ainda que agindo de forma resignada sob a tutela de um homem, seu marido, mas em todas as épocas elas estavam lá, ajudando, tornando-se sábias, deusas, filósofas, agindo ritualmente. Sem muito ligar para a política, a mulher procurou explorar seu lado intuitivo e parece ter funcionado, já que muitas benzedeiras, inclusive aquelas entrevistadas, demostraram certo ar de mães da comunidade, ou até da humanidade. Desse modo, sua construção identitária parece que primeiro passou pelos dons naturais que a mulher tem, e que necessariamente proveem de seu padrão de racionalidade. Assim, as benzedeiras mostraramse acolhedoras, honestas, como já dissemos, possuem simplicidade, atendem com motivação, creem no que fazem, em resumo, dão esperanças às pessoas.

Estar no mundo, conforme tratamos, era algo perigoso, sujeito a ataques, doenças e desastres; o homem de alguma forma precisaria se proteger, de modo que conhecer, plantas, ervas, chás, emplastros, foi uma saída para se viver bem no mundo. Desse modo, trazemos a segunda resposta possível para justificar por que e como as benzedeiras e suas práticas se inseriram socioculturalmente.

Os autores, aos quais recorremos para a fundamentação deste artigo, e as entrevistas feitas apontam para um futuro em que as benzedeiras e suas práticas terão ainda mais respeito e reconhecimento, e poderão entrar no rol da memória de nosso país. De mesmo modo, os matizes históricos dão a entender que as benzedeiras, ainda possuem um papel relevante nas cidades e vilas onde se encontram, e desenvolvem suas práticas religiosas, mágicas, proféticas. São elas que recriam os cosmos individuais, elas são uma forma personalizada de imago mundi, de centro de 'esperançamento' social.

Assim, a realidade ora observada traz consigo um desafio para o campo de estudos das ciências das religiões, em relação ao fato de que os resultados obtidos, dentro do processo de benzeção, por vezes, são eficazes, 
estão socialmente e culturalmente inseridos e ainda são bastante procurados e difundidos. A perenidade de tais práticas é atribuída a essa eficácia de que se fez menção anteriormente. Nesse escopo, as ciências das religiões devem se debruçar ainda mais sobre esse e outros temas correlacionados ao ser humano e sua condição total de cultura, religiosidade, saúde, prazer, dor, sofrimento e morte.

Para quem trabalha com seres humanos, em situações de doença ou desconforto existencial, mais especificamente, com aqueles que vivenciam a degeneração físico-existencial, é necessário aprender e não apenas a realizar técnicas assistenciais e intervenções diagnósticas ou terapêuticas, mas urge educar os especialistas para saber quando e o que falar, quando silenciar, como possibilitar posturas de compreensão, aceitação e afeto, como calar e escutar, como estar próximo e o mais acessível às necessidades das pessoas, que é o trabalho desenvolvido pelas benzedeiras em seu cotidiano, com naturalidade.

Por fim, espera-se que a publicação desse artigo possa, de fato, contribuir com a comunidade científica, em relação aos benefícios positivos das práticas religiosas das benzedeiras, dado que os problemas de saúde física e existencial que atingem o pobre, o rico, os de bairro nobre ou os de periferia, o trabalhador, o policial, o médico, o pastor, o padre, o pai, a mãe, o idoso, o recém-nascido, o cientista, enfim, atingem a todos, e, às vezes, o faz de maneira tão abrupta que somente a sabedoria popular é capaz de ouvir, entender, rezar e remediar, dar acalanto.

\section{Referências}

ALLEN, D. Myth and religion in Mircea Eliade. New York: Routledge, 1998.

BARTZ, A. A sociologia da religião de Max Weber interpretada por Pierre Bourdieu: breves apontamentos. Revista Eletrônica do Núcleo de Estudos e Pesquisa do Protestantismo (NEPP), v. 14, 2007. Disponível em: <http://www3.est.edu.br/nepp>. Acesso em: 07 Jul. 2014.

BOLTANSKI, L. As classes sociais e o corpo. Rio de Janeiro: Graal, 1989.

BOURDIEU, P. A economia das trocas simbólicas. 5. ed. São Paulo. Editora Perspectiva, 2007. BOURDIEU, P. Coisas ditas. São Paulo: Brasiliense, 1990.

BOURDIEU, P. Estruturas sociais e estruturas mentais. In: Teoria e Educação, Porto Alegre, n. 3, p. 113-119, 1991.

BOURDIEU, P. O Poder simbólico. Lisboa: Difel; Rio de Janeiro: Bertrand do Brasil, 1989. BOURDIEU, P. Razões práticas. Sobre a teoria da ação. Campinas: Papirus, 1996. 
Um olhar sobre as benzedeiras do município de Quirinópolis: 151 entre a cultura, a religião e a medicina popular

CÂNDIDO, A. J. Nossa Senhora D’Abadia: Padroeira: uma história como expressão religiosa de Quirinópolis. Goiânia: Kelps, 2010.

ELIADE, M. Imagens e símbolos: ensaio sobre o simbolismo mágico-religioso. São Paulo: Martins Fontes, 2002, 178 p.

LAPLANTINI, F. La representacion social: fenômenos, concepto y teoria. MOSCOVICI, S. (Org.) Psicologia Social II. Barcelona: Paidós, 1988.

LEMOS, C. T. Benzedura: uma forma de exercer o poder. In: Carolina Teles Lemos. (Org.). Religião e saúde. Goiânia: Deescubra, 2007, p. 19-34. (volume 2).

LEMOS, C. T. As práticas de benzedura como forma de cura no contexto do catolicismo popular brasileiro. ILEMOS, C. T.; REIMER, I. R.; SOUZA, J. O. O sagrado na vida: subsídios pra aulas de teologia. Goiânia: PUC-GO, 2009.

MACIEL, Márcia Regina Antunes; GUARIM NETO, Germano. Um olhar sobre as benzedeiras de Juruena (Mato Grosso, Brasil) e as plantas usadas para benzer e curar. Bol. Mus. Para. Emílio Goeldi. Ciênc. hum., Belém, v. 1, n. 3, p. 61-77, 2006. Disponível em: <http://www. scielo.br/scielo.php?script=sci_arttext\&pid $=$ S1981-81222006000300003\&lng $=$ en\&nrm=iso $>$. Acesso em: 30 Set. 2021.

MARCONI, Marina de Andrade; PRESOTTO, Zélia Maria Neves. Cultura. Antropologia: uma Introdução. 2. ed. São Paulo: Atlas, 1989.

OLIVEIRA, E. R. de. O que é benzeção. 2. ed. São Paulo, Brasiliense, 1985a.

OliveirA, P. A. R. de. O que é Medicina Popular. São Paulo, Brasiliense, 1985b.

OTTO, R. O Sagrado. São Leopoldo: Sinodal/EST; Petrópolis: Vozes, 2004.

SILVA, V. A. G. Benza Deus! Benzedeiras em Curitiba: modernidade e tradição: histórias de vida. Curitiba: Edição do Autor, 2009.

SOUZA, V. C. de. A ontologia do mito de Mircea Eliade: possibilidades e aspectos críticos. Estudos de Religião, v. 25, n. 41, p. 203-215, 2011. Disponível em: < https://www.metodista. br/revistas/revistas-ims/index.php/ER/article/view/2538/2785>. Acesso em: 14 Jul. 2014.

URZEDO, M. F. (Org). Quirinópolis Mãos e Olhares Diferentes 1832-2014. Goiânia: Kelps, 2014.

WEBER, Max. Economia e Sociedade. 4. ed. São Paulo: Editora UnB, 1991.

WEBER, Max. A ciência como vocação. In: WEBER, Max. Ensaios de sociologia. Rio de Janeiro: LTC, 1982.

WILLAME, J. P. Sociologia das religiões. São Paulo: Unesp, 2012.

\section{Fontes orais}

ANDRADE, Sebastiana Maria de (1943, casada, 4 filhos). Entrevista concedida a Gilson X. de Azevedo. Quirinópolis, 11 Set. 2014. 
152 Gilson Xavier de Arevedo

Carolina Teles Lemos

ARAÚJO, Dalila Fidelis (1974, casada, 5 filhos). Entrevista concedida a Gilson X. de Azevedo. Quirinópolis, 06 Jul. 2014.

CABRAL, Cleuza (1963, casada, 2 filhos). Entrevista concedida a Gilson X. de Azevedo. Quirinópolis, 16 Set. 2014.

CAMPOS, Valdivina Mendes (1934, casada). Entrevista concedida a Gilson X. de Azevedo. Quirinópolis, 22 Jul. 2014.

CUNHA, Algeníria Alves (1956, casada, 2 filhos). Entrevista concedida a Gilson X. de Azevedo. Quirinópolis, 16 Set. 2014.

MOURA, Adelícia Benedita Souza de (1954, amigada, 1 filho). Entrevista concedida a Gilson X. de Azevedo. Quirinópolis, 02 Set. 2014.

MUNIS, Joana D`Arc dos Reis (1958, casada, 2 filhas). Entrevista concedida a Gilson X. de Azevedo. Quirinópolis, 07 Out. 2014.

PEREIRA, Maria Aparecida Mendes (1961, casada, 5 filhos). Entrevista concedida a Gilson X. de Azevedo. Quirinópolis, 16 Set. 2014.

RESENDE, Marieta Souza (1944, casada, 7 filhos). Entrevista concedida a Gilson X. de Azevedo. Quirinópolis, 14 Set. 2014.

RESENDE, Marly Souza (1970, solteira, 2 filhos). Entrevista concedida a Gilson X. de Azevedo. Quirinópolis, 14 Set. 2014.

Submetido em: 1-10-2019

Aceito em: 27-1-2022 